\title{
A new species of Typhlodromus Scheuten (Acari: Phytoseiidae) from Brazil
}

\author{
ANTONIO C. LOFEGO ${ }^{1,3} \&$ REINALDO J.F. FERES ${ }^{2}$ \\ ${ }^{1}$ UNORP-Centro Universitário do Norte Paulista, Rua Ipiranga 3460, 15020-040, São José do Rio Preto, São \\ Paulo, Brazil \\ ${ }^{2}$ Departamento de Zoologia e Botânica, UNESP-Universidade Estadual Paulista, Rua Cristóvão Colombo, \\ 2265, Jardim Nazareth, 15054-000, São José do Rio Preto, São Paulo, Brazil \\ ${ }^{3}$ Corresponding author: E-mail: aclofego@ig.com.br
}

\begin{abstract}
A new species of phytoseiid mites is described from Brazil, Typhlodromus moraesi sp. nov., collected on Tabebuia alba (Cham.) Sandwith and Chamaesyce hirta (L.) Millsp. in the State of São Paulo. This is the second species of the T. arizonicus group.
\end{abstract}

Key words: Phytoseiidae, Typhlodromus arizonicus group, Typhlodromus moraesi sp. nov.

\section{Introduction}

Only a single species of the genus Typhlodromus (Phytoseiidae: Typhlodrominae) has been included in the $T$. arizonicus species group, namely $T$. arizonicus (Tuttle \& Muma), found in Arizona, USA. This species group is characterized by the presence of setae z3, s6, S2, S5, R1, JV2 and JV3 and by the absence of z6, Z1, S4 and JV4 (Chant \& McMurtry, 1994). A second species of this group, T. moraesi sp. nov., is described and illustrated in this paper, from specimens collected in the State of São Paulo, southeastern Brazil, on Tabebuia alba (Cham.) Sandwith (Bignoniaceae) and Chamaesyce hirta (L.) Millsp. (Euphorbiaceae). In the region where this mites was found, the weather is of the type CwaAw of Köppen, with two distinct seasons: one wet, from October to March, and the other dry, from April to September. The dry season includes just $15 \%$ of the total annual precipitation of about $1,200 \mathrm{~mm}$. The annual mean temperature is $25^{\circ} \mathrm{C}$, with a maximum mean of $30^{\circ} \mathrm{C}$ and a minimum mean of $20^{\circ} \mathrm{C}$ (Barcha \& Arid, 1971; Arid \& Barcha, 1973). 